\title{
The International Year of Planet Earth (2007-2009): Earth Sciences for Society
}

1 Chair, Board of Officers, International Year of Planet Earth.E-mail: e.demulder@planet.nl

2 Chair, Outreach Programme Committee, International Year of Planet Earth.E-mail: ted.nield@geolsoc.org.uk

3 Chair, Science Programme Committee, International Year of Planet Earth. E-mail: edwardderbyshire@btopenworld.com

Last December the United Nations General Assembly voted unanimously to approve 2008 as International Year of Planet Earth. This ambitious research and outreach project, which will actually extend over three years, is Earth science's big chance to put itself back at the centre of public science awareness. All it needs now - apart from $\$ 20 m-i s$ you ...

\section{Summary}

Natural disasters like the 2004 tsunami bear graphic testimony to the Earth's incredible power. More effective use of geoscientific knowledge can save lives and protect property. Such knowledge also enables us to satisfy, in a sustainable manner, the growing need for Earth's resources by an expanding human population.

Such knowledge is readily available in the practical experience and publications of some half a million Earth scientists all over the world, a professional community that is ready and willing to contribute to a safer, healthier and wealthier society if called upon by politicians and decision makers. Professional guidance by Earth scientists is available in many aspects of everyday life including, for example, identification of the best areas for urban expansion, sites to avoid for waste disposal, the location of new underground fresh water resources, and where certain toxic agents implicated in Earth-related diseases may be located, etc. The International Year of Planet Earth (2007-2009) aims to build on existing knowledge and make it more available for the improvement of everyday life, especially in the less developed countries, as expressed in the Year's subtitle: Earth sciences for Society.

Ambitious outreach and science programmes constitute the backbone of the International Year, now politically endorsed by all 191 member states of the United Nations Organisation which has proclaimed 2008, the central year of the triennium, as the UN Year of Planet Earth. This paper describes who is behind the initiative, how it will work, and how the political process leading to United Nations proclamation proceeded. It also describes the financial and organisational aspects of the International Year, sets out the commitments necessary for the realization of the Year's ambitions by all nations, and explains how the raising of US\$ 20 million will be approached.

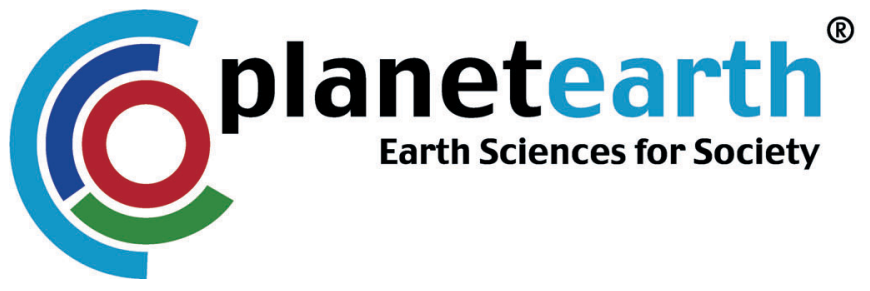

Figure 1 Logo of the International Year of Planet Earth. In 2002, the German Ministry of Education and Research instigated the very successful Jahr der Geowissenschaften. The logo used in that national event forms the basis of the logo of the International Year of Planet Earth, by kind permission of the German Ministry. This consists of an inner circle (red) representing the solid Earth, then the biosphere in green and the hydrosphere in dark blue, above which is the pale blue atmosphere, all constituents of the Earth System.

\section{Aims, ambitions and target groups of the International Year of Planet Earth}

The International Year of Planet Earth is designed to foster outreach and research activities with the single purpose of raising worldwide public and political awareness of the vast (but often under-used) potential of Earth Sciences for improving the quality of life and safeguarding the planet. Its desired outcomes are raising public awareness and enhancing research, in both developed and lessdeveloped countries (LDCs), with all the attendant capacity-building that this will entail. The International Year of Planet Earth envisages a significantly expanded role for the Earth Sciences in building a healthier, safer and wealthier society.

Among a range of objectives, the International Year aims to:

- Reduce risks to society posed by natural and human-induced hazards, through current knowledge and new research

- Reduce health problems of mankind by improving understanding of the medical aspects of Earth Science

- Discover new natural resources and make them available in a sustainable manner

- Build safer structures and expand urban areas, utilizing natural subsurface conditions

- Determine the non-human factor in climatic change

- Improve knowledge concerning the occurrence of natural resources (as groundwater), which are often sources of political tension between neighbouring countries.

- Improve understanding of unique conditions on ocean floors relevant to the evolution of life.

and, at a more general level, to:

- Stimulate interest in the Earth sciences within society at large

- Expand the number of students in the Earth sciences 
- Increase budgets for Earth science related research

- Promote exposure and application of geosciences

- Promote sustainable extraction of Earth's resources.

Target groups of the International Year of Planet Earth include: (1) decision makers and politicians who need to be better informed about how Earth science knowledge can be used for sustainable development, (2) the voting public, who need to know how Earth science knowledge can contribute to a better society, (3) fellow geoscientists, who are very knowledgeable about various aspects of the Earth but who need help in using their knowledge for the benefit of the world's population.

\section{Who is behind the International Year?}

\section{Initiators \& Partners}

The project was jointly initiated in 2000 by the International Union of Geological Sciences (IUGS) and the United Nations Educational, Scientific and Cultural Organisation's (UNESCO) Earth Science Division. IUGS, which is a Non-Governmental Organisation, and UNESCO, an Inter-Governmental Organisation, have enjoyed several decades of productive cooperation, notably through their joint International Geoscience Programme (IGCP).

The project has attracted 12 Founding Partners that actively support the initiative either in kind or in cash. They are:

(1) the International Union of Geodesy and Geophysics (IUGG);

(2) the International Geographical Union (IGU);

(3) the International Union of Soil Sciences (IUSS);

(4) the International Lithosphere Programme (ILP);

(5) the Geological Survey of the Netherlands TNO (TNO);

(6) the Geological Society of London (GSL);

(7) the International Soil Reference and Information Centre (ISRIC);

(8) a consortium of the International Association of Engineering Geologists and the Environment (IAEG), the International Society of Rock Mechanics (ISRM) and the International Society of Soil Mechanics and Geotechnical Engineering (ISSMGE);

(9) the International Union for Quaternary Research (INQUA);

(10) the American Geological Institute (AGI);

(11) the American Association of Petroleum Geologists (AAPG); and

(12) the American Institute of Professional Geologists (AIPG).
In addition, the International Year of Planet Earth enjoys the support of 26 Associate partners including all major international geoscientific and other relevant organisations (Table 1).

The geoscience community has expressed its support for this initiative in the form of written declarations from the national geoscience committees of 44 nations. Moreover, a Declaration in support of the International Year was unanimously adopted by representatives of geoscientific communities in 140 countries at the 32nd International Geological Congress in Italy, in August 2004.

\section{Timing}

The UN Year (2008) is centred in a triennium starting in 2007 and running to the end of 2009. Fundraising and developing the Secretariat began early in 2006. Most activities in 2007 will be concerned with raising awareness among the general public as a prime target. This will break ground for the UN-Year (2008) when outreach activities and the generation of political awareness will culminate. At the same time, the first project grants will be awarded for work on the Year's scientific themes. These will reach a peak of activity by 2009 , by which time the first answers to questions posed by the International Year of Planet Earth will emerge. Formal activities for the International Year will wind up by mid-2010.

\section{Outreach Programme}

Outreach lies close to the heart of the International Year because of its prime aim to generate interest and greater awareness among the general public, decision makers and politicians about the effective application, for the benefit of human society, of the widely available wealth of information in the hands of the Earth science community. The publication of the Year's first brochure: Planet Earth in our hands was a step in that direction, quickly followed by the brochure on Outreach, bringing Earth sciences to everyone.

The outreach programme will invite any interested party or group to submit international project proposals addressing the above-mentioned aims. For example, these may take the form of events, event listing, and badging; cooperation for increased visibility; recycling of educational material; 'citizen science', involving the public in research; competitions; special magazine supplements; books, story ideas; support for TV documentary or other programme-making; art commissioning.

Table 1 Associate Partners of the International Year of Planet Earth.

\begin{tabular}{|c|c|c|c|}
\hline ICSU & International Council for Science & GSAf & Geological Society of Africa \\
\hline IOC & Intergovernmental Oceanographic Commission of & UNU & United Nations University \\
\hline & UNESCO & AGID & Association of Geoscientists for International Develop- \\
\hline IPA & International Permafrost Association & & ment \\
\hline IAGOD & International Association on the Genesis of Ore Deposits & \multirow[t]{2}{*}{ UN/ISDR } & United Nations International Strategy for Disaster Reduc- \\
\hline SEG & Society of Economic Geologists & & tion \\
\hline SGA & Society for Geology Applied to Mineral Deposits & NESF & North-eastern Science Foundation (USA) \\
\hline IAH & International Association of Hydrogeologists & AASG & Association of American State Geologists \\
\hline IGCP & International Geoscience Programme IGCP & \multirow[t]{2}{*}{ ISPRS } & International Society of Photogrammetry and Remote \\
\hline EFG & European Federation of Geoscientists & & Sensing \\
\hline AARSE & African Association of Remote Sensing of the Environ- & GSA & Geological Society of America \\
\hline & ment & \multirow[t]{2}{*}{ NACSN } & North American Committee for Stratigraphic Nomencla- \\
\hline SCA & Science Council of Asia & & ture \\
\hline \multirow[t]{2}{*}{ ProGEO } & European Association for the Conservation of the & \multirow[t]{2}{*}{ CPC } & Circum Pacific Council for Energy and Mineral \\
\hline & Geological Heritage & & Resources \\
\hline SEPM & Society for Sedimentary Geology & IPA & International Palaeontological Association \\
\hline CCOP & $\begin{array}{l}\text { Coordinating Committee for Geoscience Programmes in } \\
\text { East and Southeast Asia }\end{array}$ & CGMW & Commission for the Geological Map of the World \\
\hline
\end{tabular}




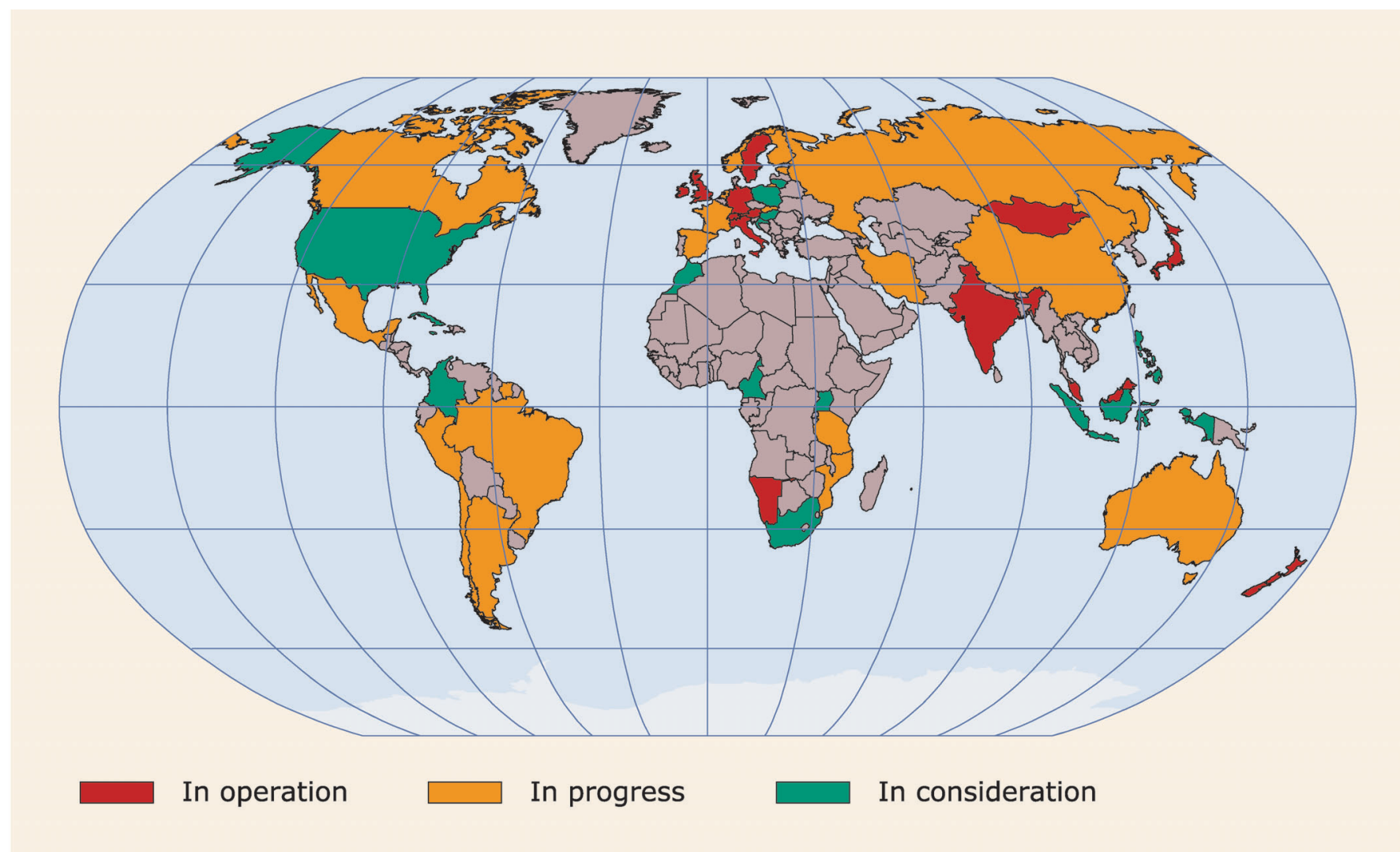

Figure 2 Map displaying progress in developing national committees by May 2006.

\section{Science Programme}

The scientific themes selected for the International Year of Planet Earth were all determined on the basis of their relevance to Society. The selected themes are:

- Groundwater: reservoir for a thirsty planet?

- Hazards: minimizing risk, maximizing awareness

- Earth and Health: building a safer environment

- Climate change: the 'stone tape'

- Resources: towards sustainable use

- Megacities: our global urban future

- Deep Earth: from crust to core

- Ocean: abyss of time

- Soil: Earth's living skin

- Earth and Life: origins of diversity.

Specific questions, identified within each of these themes, have been designed to attract project proposals with the potential to provide answers to a range of societal problems facing politicians and decision-makers. Scientists are invited to submit Expressions of Interest (EoIs), followed by full project proposals for work within these themes, addressing the special topics within them. Selection criteria for seed money grants (only) require proposals to be geoscience-based, truly international, holistic and multidisciplinary, to have human impact, and to have potential for developing countries and for outreach.

Implementation of the science programme will involve close cooperation with the International Geoscience Programme (IGCP), the global UNESCO-IUGS programme that has run successfully for more than 33 years. Brochures have been printed for all science themes and are downloadable from the Year's website (www.yearofplanetearth.org).

\section{National committees}

Success or failure of the International Year's ambitions will largely depend on how these are realised at national and local levels. For that reason, the Year's national committees are perhaps the most important structural components of the Year of Planet Earth because their activities will be most clearly visible to the public. Every country is encouraged to create such a committee. By May 2006 National Committees had been created in Austria, Germany, India, Ireland, Italy, Japan, Malaysia, Mongolia, Namibia, New Zealand, Sweden, Switzerland and UK, whereas some 20 other nations were developing such committees, and 13 more considered doing so (see Figure 2). National committees are independent bodies and raise their own funds from national resources. Through the Year's logo and eventlisting, the Corporation gives world wide exposure to their activities. To formalize such cooperation, national committees are invited to sign a Memorandum of Understanding with the International Corporation.

\section{The route travelled - towards UN proclamation}

The International Year of Planet Earth chose the UN-route mainly because: (1) proclamation by the United Nations will commit all 191 UN member countries to stimulate national politicians and decision makers to use the Earth sciences as means of advancing sustainable development in their countries, and will report back to the UN on the progress made; (2) UN proclamation gives credibility to the claim that this initiative is widely accepted by all nations as a most worthy endeavour, and will thus be instrumental in 


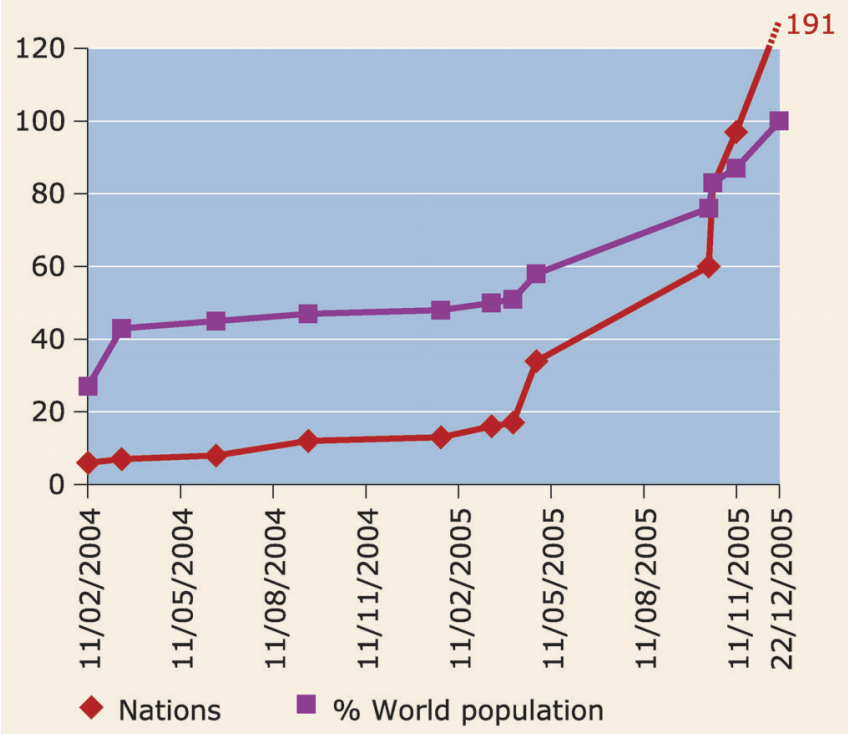

Figure 3 Development of political support for the International Year of Planet Earth.

approaching donors and sponsors for financial contributions to realise the Year's aims.

Three milestones marked the key stages along the road map to UN proclamation: (1) adoption of a Resolution by UNESCO's Executive Board; (2) adoption of a Resolution by UNESCO's General Conference, (3) adoption of a Resolution by the UN General Assembly.

The first milestone was reached on 28 April 2005 when a Draft Resolution, tabled by the Permanent Delegation of the United Republic of Tanzania, was adopted unopposed. The second was the unopposed adoption on 19 October 2005 of a draft Resolution by UNESCO's 33rd General Conference, during which it was recommended that the UNESCO National Committees should create national groups for the purpose of implementing the Year and collaborating with Earth science societies and groups throughout the world, including the less developed countries. The third milestone was passed when the United Republic of Tanzania again took the lead among a core group of 82 nations in co-sponsoring a Draft Resolution in the United Nations General Assembly. On 22 December 2005, the UN General Assembly, with reference to the World Summit on Sustainable Development, adopted by consensus Resolution 60/192 proclaiming 2008 as the International Year of Planet Earth.

\section{Relation to other science years}

Three other international science years, none of which has sought UN-Year status, will run at the same time as the International Year of Planet Earth. These are the International Heliophysical Year (IHY), the electronic Geophysical Year (eGY), and the International Polar Year (IPY). Each of the four international years has its own distinctive target groups, ambitions and parties involved, though all share the view that a better understanding of the Earth System is the key to sustainable development. The four initiatives have agreed to maintain close communication and to cooperate with each other, coupling their science and outreach programmes wherever possible and appropriate. This spirit of cooperation is formally stated in the Celimontana Declaration.

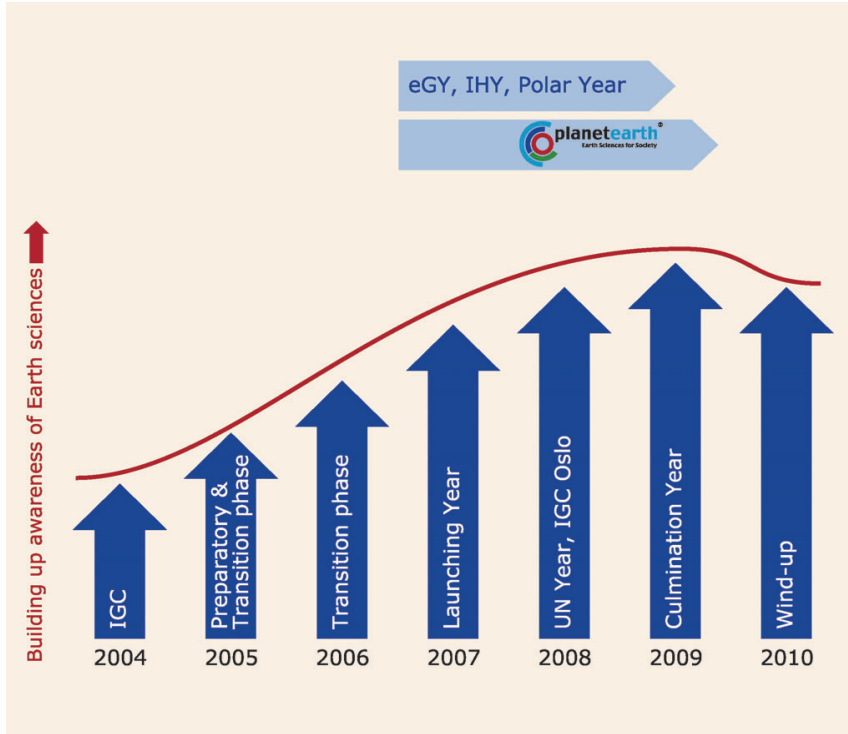

Figure 4 Relationship between the International Year of Planet Earth and other science year initiatives.

\section{Financial aspects of the International Year of Planet Earth}

Upon UN proclamation, a fund-raising campaign was launched. Substantial funds will be needed for science and outreach activities at both national and international levels. At the international level, a budget of about US\$20 million will be required to realize at least part of the Year's ambitious programmes.

The science and outreach programmes require US\$ 9 million each. A minimum budget requirement for implementation of such an international programme is US\$ 5 million. Potential sponsors and donors will be approached by members of the Year's Development Committee. The funds will be managed by the Corporation (see below).

The preparation costs of the International Year of Planet Earth were jointly covered by the initiators, Founding Partners and sponsors. The amount of cash money accumulated over the period 2001 2005 was US $\$ 414,894$, but at least twice this figure was invested in the form of salary costs and out-of-pocket expenses and support-inkind, provided by the Initiators and Founding Partners. Most of the cash went into the production of the Year's series of science and outreach brochures, leaflets and posters. Other major items of expenditure included meetings and promotion, including work involved in encouraging a range of organisations to partner the initiative. For more information please go to $w w w$.yearofplanetearth.org.

\section{Potential sponsor and donor organisations}

The main and compelling incentive for sponsors and donors of the International Year of Planet Earth during the triennium is the substantial attention to be given to the integral relation between the Earth sciences and numerous aspects of society. Given that these involve the (sustainable) use of Earth materials, promotion of the current and future value of such materials for society will not only benefit the extraction industry, but will have wide-ranging societal impact. As the International Year also aims to contribute to a safer 
society, the use of Earth science knowledge and understanding of natural and man-induced hazards will also be of interest to insurance companies, development banks and organisations dealing with hazard prevention and mitigation.

Equally, the Year's work in contributing to a healthier society can be expected to interest the pharmaceutical industry, the World Health Organisation and other bodies active in this burgeoning field. Several other sectors and related industries and organisations should be able to profit from increasing public awareness of the Earth sciences and their direct or indirect contribution to the wellbeing of local communities, and of society at large.

\section{Organisation and liability}

The organisational structure of the International Year evolved as the Initiative grew in significance. By mid 2002, a Science Programme Committee (SPC) and an Outreach Programme Committee (OPC) had been installed, leading towards the development of a Management Team that reports to IUGS and UNESCO. On March 16, 2006, the International Year of Planet Earth was registered as a not-forprofit 501 (c) (3) organisation under the law of the State of Delaware, USA. The Corporation reflects the responsibilities of the stakeholders and players in the Year and consists of a Board with responsibility for decision making and a Secretariat to manage dayto-day operations at the international level. As the Corporation wishes to outsource the Secretariat activities, open invitations have been sent to organisations with long-standing professional reputations, inviting them to bid for the contractual hosting of the Secretariat. Finally, the Corporation has three advisory bodies: the Senior Advisers, the Goodwill Ambassadors and the Patrons. These bodies advise the Board and its Officers, the Secretariat and the national committees on all relevant issues, including fund raising. Patrons are typically Heads of State or persons of comparable stature. By May 2006, two Patrons had accepted our invitation to serve in this capacity.

Dr Eduardo de Mulder is a geoscientist who has worked for the Geological Survey of The Netherlands for more than 30 years. During his career in the Survey he became involved in environmental, engineering and urban geology. In 1998 he was appointed as a Professor in Subsurface Management at the Technical University in Delft, The Netherlands. He was Secretary-General and Chairman of the IUGS Commission on Geology for Environmental Planning, Treasurer of INQUA, and President of IUGS from 2000-2004. He has been leading the activities of the International Year of Planet Earth, now as the Chair of the Board of Officers.

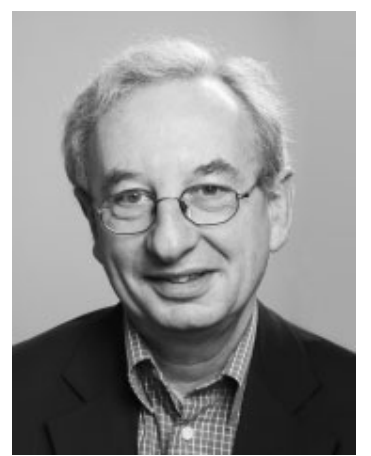

Dr Ted Nield is a science journalist who works for the Geological Society of London. He has written for most UK broadsheet newspapers and popular science magazines, and also published two palaeontology textbooks with Pergamon Press. His novel Dead Clever (1997) was serialised in the Times Higher Education Supplement in 1997. He is Editor of the Society's monthly colour news magazine Geoscientist, and of www.geolsoc.org.uk. Ted Nield is Chairman of the Association of British Science Writers, the UK's national body for science communicators. His next book, Supercontinent-our once and future world, will be published by Granta in 2007.

Professor Edward Derbyshire is an earth scientist with research interests in silt, especially glacial and aeolian (loess), including health impacts of atmospheric dust. He has held chairs in the U.K. and Australia, and visiting chairs in The Netherlands and New Zealand. He is Research Professor in Quaternary Science at Royal Holloway (University of London), Emeritus Professor, University of Leicester, and Honorary Professor, Gansu Academy of Sciences, Lanzhou, China. He was INQUA Secretary-General 1991-95, chaired the IGCP Scientific Board 1997-2001, and now chairs the International Year of Planet Earth's Science Programme. He is author or co-author of more than 250 scientific publications.
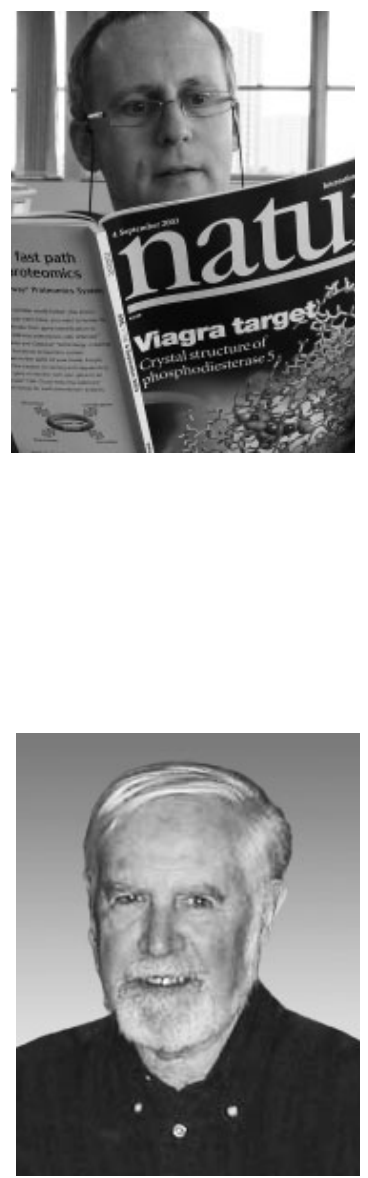